\title{
APLIKASI INFORMASI PELAPORAN DAN PENEMUAN BARANG TERTINGGAL BERBASIS ANDROID (STUDI KASUS: PT KERETA COMMUTER INDONESIA)
}

\author{
1) Muhamad Ridwan Shobari, ${ }^{2}$ ) Fajar Masya \\ ${ }^{1,2)}$ Sistem Informasi, Ilmu Komputer, Universitas Mercubuana \\ 1,2) J1. Meruya Selatan No.31, RT.4/RW.1, Meruya Sel., Kec. Kembangan, Kota Jakarta Barat, Daerah \\ Khusus Ibukota Jakarta 11610 \\ E-Mail : ridwanshobari26@gmail.com,fajar.masya@mercubuana.ac.id
}

\begin{abstract}
ABSTRAK
Dalam melakukan proses pelaksanaan pelaporan dan penemuan barang yang tertinggal di PT Kereta Commuter Indonesia dilakukan dengan mekanisme yang masih menggunakan membuat surat kehilangan. Ketika Penumpang ingin mengetahui barang yang tertinggal dilaporkan kepada petugas stasiun maka harus menghubungi petugas passenger dan mengisi formulir kehilangan kemudian dari pihak passenger service tersebut koordinasi via mobile phone untuk mengetahui posisi barang tersebut. Menurut hasil wawancara dengan petugas passenger service, saat ini pelaporan dan penemuan barang tertinggal jumlahnya masih sangat tinggi setiap harinya tercatat satu stasiun rata-rata ada 9 laporan penemuan barang dan 6 laporan kehilanganMetode yang digunakan dalam analisis adalah metode PIECES, metode PIECES adalah metode analisis sebagai dasar untuk memperoleh pokok-pokok permasalahan yang lebih spesifik. Dalam menganalisis sebuah sistem, biasanya akan dilakukan terhadap beberapa aspek antara lain adalah kinerja, informasi, ekonomi, keamanan aplikasi, efisiensi dan pelayanan pelanggan. sedangkan metode pengumpulan data yang digunakan dalam penelitian ini adalah studi pustaka, observasi dan wawancara. Hasil penelitian ini menghasilkan sebuah aplikasi berbasis android yang dapat digunakan oleh pihak PT Kereta Commuter Indonesia, Khususnya Petugas Passenger Service dalam pelaporan dan penemuan barang tertinggal.
\end{abstract}

Kata Kunci: Pelaporan, Penemuan, Pemberitahuan informasi.

\section{ABSTRACT}

In carrying out the process of carrying out the reporting and discovery of items left behind at PT Kereta Commuter Indonesia, it is carried out with a mechanism that still uses making loss letters. When Passengers want to know the items left behind are reported to station officials, they must contact the passenger officer and fill out the loss form, then the passenger service coordinate via mobile phone to find out the position of the goods. According to interviews with passenger service officers, the number of reports and inventions of goods left behind is still very high every day. There are one station recorded on average, there are 9 reports of goods discovery and 6 reports of loss. The method used in the analysis is the PIECES method, the PIECES method is the analysis method as a basis for obtaining more specific issues. In analyzing a system, it will usually be carried out on several aspects including performance, information, economy, application security, efficiency and customer service. while the data collection methods used in this study are literature studies, observations and interviews. The results of this study produce an android-based application that can be used by PT Kereta Commuter Indonesia, especially the Passenger Service Officers in reporting and finding lost goods.

Keywords: Reporting, Discovery, Notification of information.

\section{PENDAHULUAN}

Transportasi $\mathrm{krl}$ adalah transportasi pilihan utama kaum urban berupa 1 rangkaian kereta yang berbasis rel listrik. Untuk saat ini transportasi $\mathrm{krl}$ hanya beroperasi di jabodetabek dan sekitarnya. Transportasi ini menjadi pilihan utama bagi 1.6 juta lebih penduduk sekitar jabodetabek karena keunggulannya yaitu bersih, nyaman, murah dan bebas macet. Tidak hanya menjadi transportasi untuk pulang - pergi menuju 
tempat bekerja, krl juga menjadi pilihan untuk menuju tempat-tempat wisata di wilayah dki jakarta seperti monas, masjid istiqlal, kota tua, ancol, ragunan dan lain-lain [15].

PT. Kereta Api Indonesia (KAI) adalah perusahaan induk perkeretaapian di Indonesia PT. Kereta Api Indonesia (KAI) sendiri telah meluncurkan sebuah perusahaan baru, yakni Kereta Commuter Indonesia. Pembentukan anak perusahaan ini berawal dari keinginan para stakeholdernya untuk lebih fokus dalam memberikan pelayanan yang berkualitas dan menjadi bagian dari solusi masalah transportasi perkotaan yang semakin kompleks. Perseroan ini resmi menjadi anak perusahaan PT KERETA API INDONESIA (Persero) sejak tanggal 15 September 2008. Kelebihan dari Kereta Commuter Indonesia (KCI) ini adalah menjangkau kurang lebih 80 stasiun dan memiliki jam keberangkatan yang lebih banyak. Selain itu, fasilitas yang dimiliki Kereta Commuter Indonesia sangat baik dan harga yang lebih efisien[14].

Menurut hasil wawancara dengan petugas passanger service, saat ini pelaporan dan penemuan barang tertinggal jumlahnya masih sangat tinggi setiap harinya tercatat satu stasiun rata-rata ada 9 laporan penemuan barang dan 6 laporan kehilangan menurut data dari passanger service. Kemudian petugas passanger service masih menggunakan system yang sangat rumit dan kurang efektif. Akibatnya, sangat membutuhkan waktu untuk pelaporan dan penemuan itu sendiri . Selain itu, Passanger Service. Sulit mencari data barang tertinggal yang masih menggunakan buku pelaporan. Kemudian untuk mencari info barang tertinggal harus menghubungi via voip petugas passanger stasiun akhir apakah barang tersebut ada atau tidaknya. Akibatnya banyak penumpang yang mengeluh karena sistem yang masih rumit dan membutuhkan waktu yang lama dalam mengakses keberadaan informasi barang tertinggal tersebut[17].

Oleh karena itu, diusulkan untuk membuat Aplikasi Informasi Pelaporan dan Penemuan barang tertinggal Berbasis Android di PT Kereta Commuter Indonesia, sebagai salah satu alternative yang tepat guna dan efektif untuk pengguna smartphone saat ini, yang sudah menjadi kebutuhan bagi semua masyarakat di semua kalangan. Kita dapat membuat sebuah aplikasi yang dapat di implementasikan ke dalam device android yang mendukung fitur tersebut[13].

Android adalah sistem operasi yang berbasis kernel linux untuk menjembatani antara device dan pengguna, Berdasarkan uraian masalah tersebut, penulis membuat "Aplikasi Informasi Pelaporan dan Penemuan Barang Tertinggal Berbasis Android", diharapkan akan dapat menjadi solusi untuk masalah - masalah yang dihadapi oleh petugas Passanger Service PT Kereta Commuter Indonesia[13].

\section{Tujuan Penelitian}

1. Untuk membantu meningkatkan system pelayanan pada PT. Kereta Commuter Indonesia khususnya petugas passanger service dalam menangani pelaporan dan penemuan barang tertinggal.

2. Tujuan operasional dari penelitian ini adalah untuk mengetahui kendala-kendala apa saja pada system pelaporan dan penemuan yang sedang berjalan saat ini

3. Tujuan fungsional dari penelitian ini yaitu agar hasil dari penelitian ini dapat dimanfaatkan oleh PT.Kereta Commuter Indonesia sebagai referensi dasar untuk mengambil satu langkah kebijakan yang berhubungan dengan informasi pada bagian pelayanan pelaporan dan penemuan barang tertinggal. Sehingga dapat mempercepat proses pelaporan dan 
penemuan serta menghasilkan informasi data yang akurat dan efisien.

4. Tujuan individual adalah untuk menambah ilmu pengetahuan, pengalaman, pengenalan, dan pengamatan sebuah system informasi pelaporan dan penemuan barang tertinggal pada PT.Kereta Commuter Indonesia.

\section{METODE}

\section{Lokasi Penelitian}

Lokasi penelitian ini untuk memperoleh datadata yang diperlukan dalam membuat aplikasi ini adalah daerah Stasiun Angke Jl. Jembatan Lima, Tambora, Jakarta Barat

\section{Sarana Pendukung}

Adapun sarana pendukung yang dibutuhkan untuk Analisis Perancangan Sistem Plaporan dan Penemuan Barang Tertinggal PT Kereta Commuter Indonesia :

Tabel 1. Spesifikasi hardware

\begin{tabular}{ll}
\hline \multicolumn{1}{c}{ Nama } & \multicolumn{1}{c}{ Spesifikasi } \\
\hline Screen resolution & $1336^{*} 768$ pix \\
\hline processor & Intel Core i3 \\
\hline RAN & $4 \mathrm{~Gb}$ \\
\hline hardisk & $500 \mathrm{~Gb}$ \\
\hline
\end{tabular}

Tabel 2. Spesifikasi Software

\begin{tabular}{ll}
\hline \multicolumn{1}{c}{ Perangkat Luank } & \multicolumn{1}{c}{ Spesifikasi } \\
\hline Sistem Operasi & Windows 10 \\
\hline Database Server & Firebase \\
\hline Web Server & $\begin{array}{l}\text { Node js, android } \\
\text { studio, java script, } \\
\end{array}$ \\
& css \\
\hline Script Editor & Visual code \\
\hline Web Browser & Google Chrome, \\
& Mozilla Firefox \\
\hline
\end{tabular}

\section{Diagram alir Penelitian}

Untuk mempermudah dalam pengerjaan penelitian ini, maka penulis membuatkan kerangka kerja penelitian seperti pada gambar 1 berikut ini.

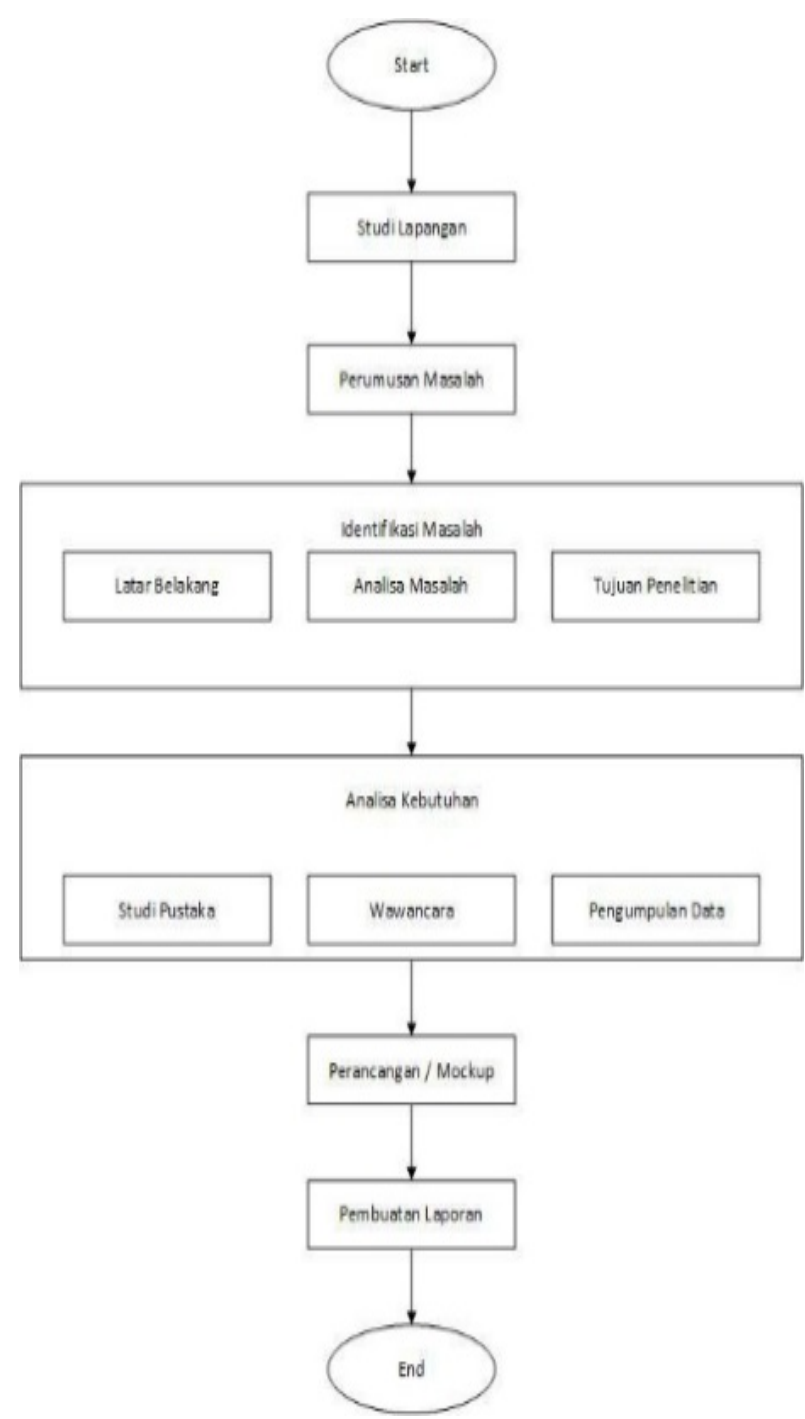

Gambar 1. Diagram Alir Penelitian

\section{HASIL}

Pada proses berjalan pelaporan dan penemuan barang tertinggal di PT. Kereta Commuter Indonesia masih harus mengisi formulir dari petugas passanger service, kemudian petugas passanger service mendata kembali di buku laporan passanger service dan menunggu informasi barang tertinggal tersebut. Hal tersebut akan memakan banyak waktu di karenakan pada saat melakukan proses pengambilan maupun pelaporan barang 
tertinggal masih menggunakan pendataan tertulis. Kendalanya adalah, dengan rata-rata perharinya ada 9 laporan barang temuan dan 6 laporan kehilangan perstasiun, sangat membutuhkan waktu untuk pencarian data dan resiko kerusakan dan kehilangan data, hal tersebut akan sangat memakan banyak waktu mengingat efektifitas waktu sangat berpengaruh di zaman yang serba digital ini. Adapun proses berjalan untuk pelaporan dan penemuan barang tertinggal adalah sebagai berikut :

1. Petugas passanger service memberikan formulir kepada penumpang.

2. Kemudian penumpang mengisi biodata pada formulir tersebut dan memberikan kepada petugas passanger service.

3. Setelah petugas passanger service menerima formulir tersebut dari penumpang, petugas passanger service melakukan pendataan kembali di buku laporan harian.

4. Selanjutnya petugas passanger service mengkonfirmasi ke petugas passanger stasiun penemuan.

5. Kemudian petugas passanger service menginformasikan penumpang status barang tersebut.

6. Selanjutnya penumpang mengisi formulir pengambilan barang tertinggal jika sudah ditemukan dari petugas passanger service.

7. Setelah penumpang mengisi formulir pengambilan barang petugas passanger service mendata kembali bahwa barang tersebut sudah ditemukan.

8. Kemudian petugas passenger service mengumpulkan formulir pengambilan barang di file

9. Kemudian pengawas mengelola barang tertinggal dan menyesuaikan dengan data barang mana saja yang sudah expired

\section{Usulan Rancangan Sistem Informasi \\ Use Case Diagram Berjalan}
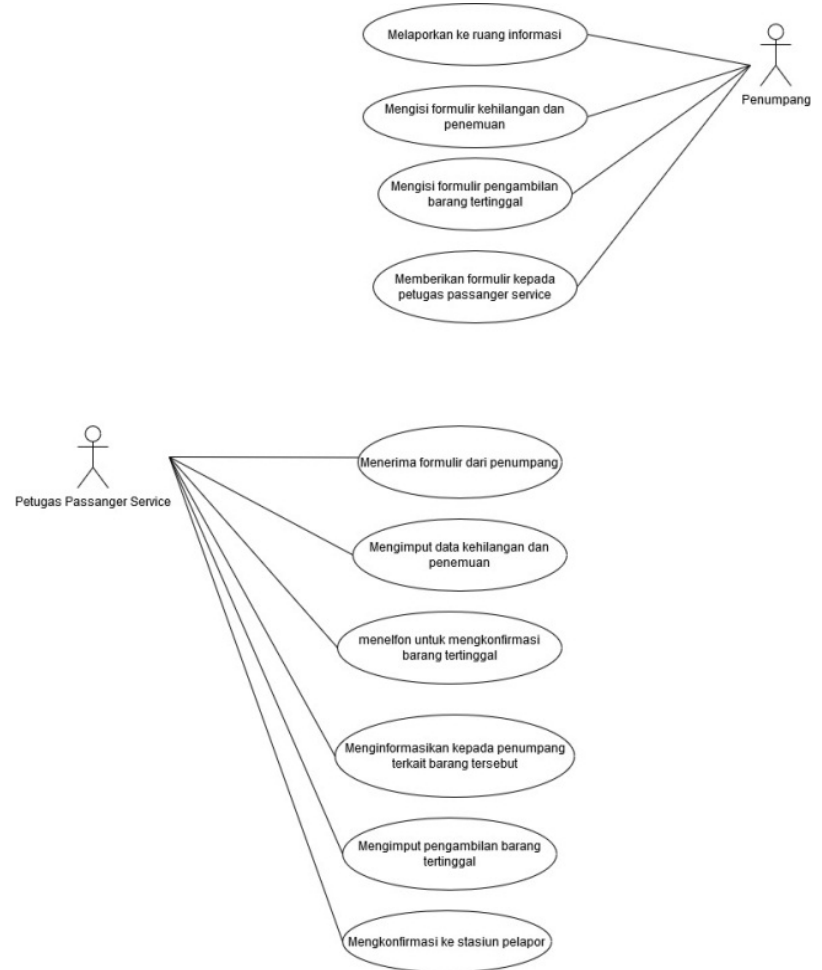

Gambar 2. Use Case Diagram Berjalan

\section{Use Case Diagram Usulan}

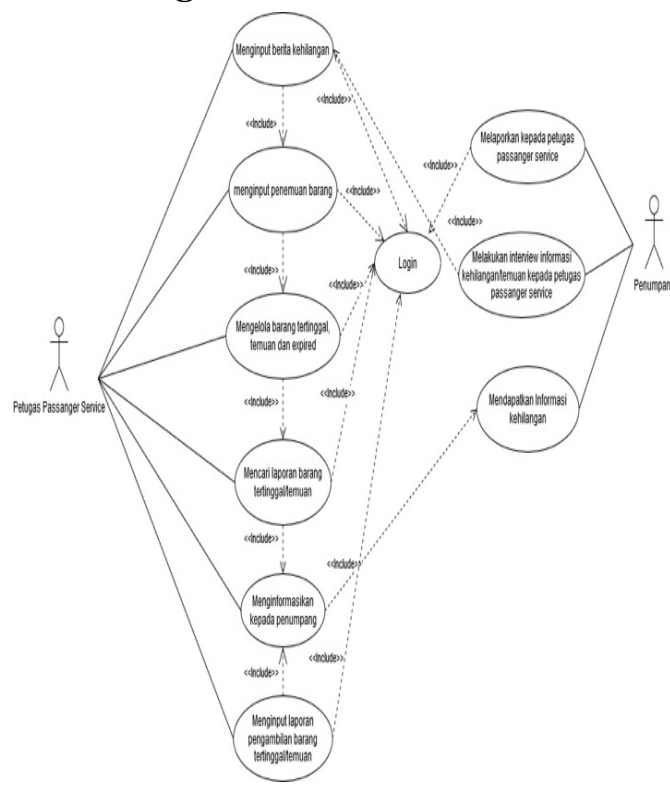

Gambar 3. Use Case Diagram berjalan 


\section{Activity Diagram Login}

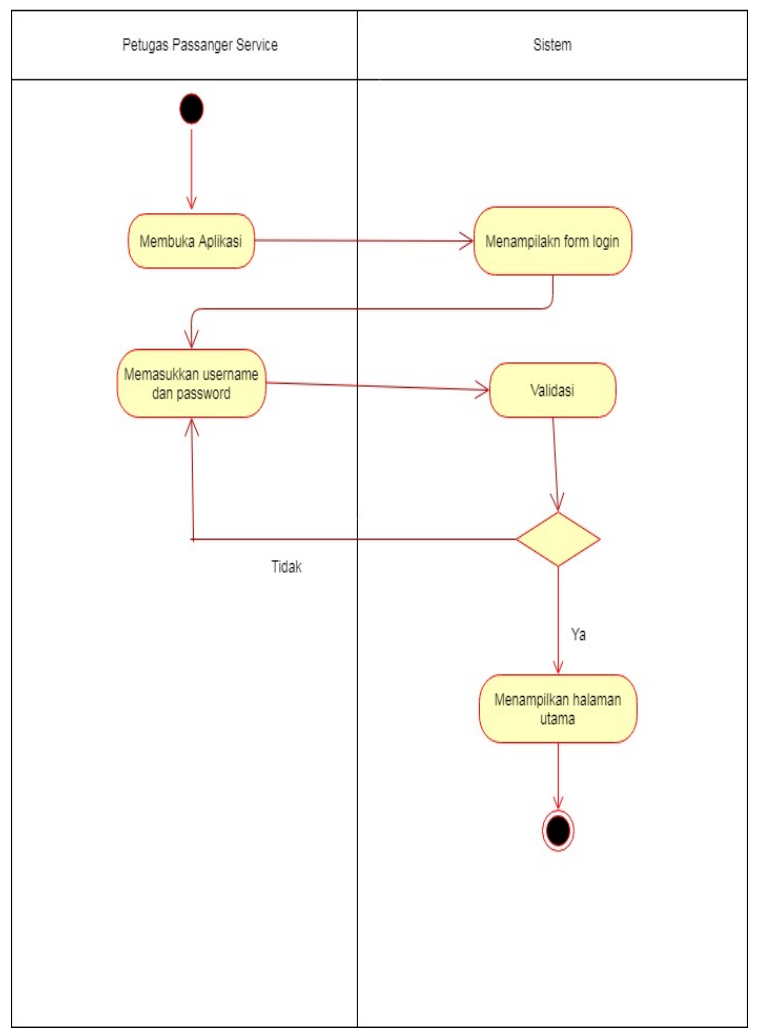

Gambar 4. Activity Diagram Login

Berikut adalah penjelasan Activity Diagram Login

1. Petugas passanger service membuka aplikasi

2. Sistem menampilkan tampilan login

3. Petugas passanger service memasukkan username dan password

4. System akan memvalidasi data yang dimasukkan oleh petugas

5. Jika username dan password sudah benar maka sistem akan menampilkanhalaman

Utama/dashboard

6. Jika username dan password tidak benar maka sistem akan menampilkan notifikasi gagal login dan petugas mengisi kembali form login
Activity Digram Pencarian Laporan Barang Hilang Dan Temuan

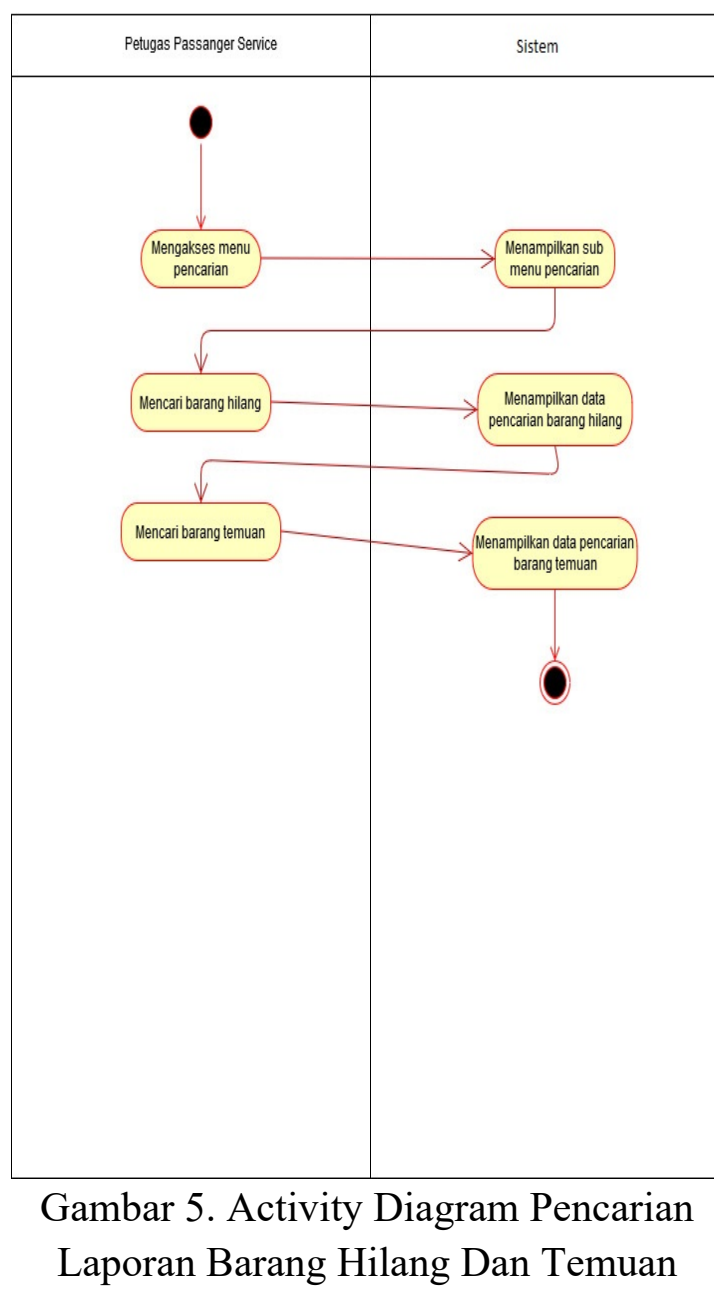

Berikut adalah penjelasan Activity Diagram Pencarian Laporan Barang Hilang Dan Temuan

1. Petugas mengakses tampilan menu pencarian

2. System menampilkan submenu pencarian barang temuan/barang kehilangan

3. Petugas memilih barang hilang

4. System menampilkan data pencarian barang hilang

5. Petugas memilih barang temuan

6. System menampilkan data pencarian barang temuan 
Activity Diagram Input Berita Kehilangan

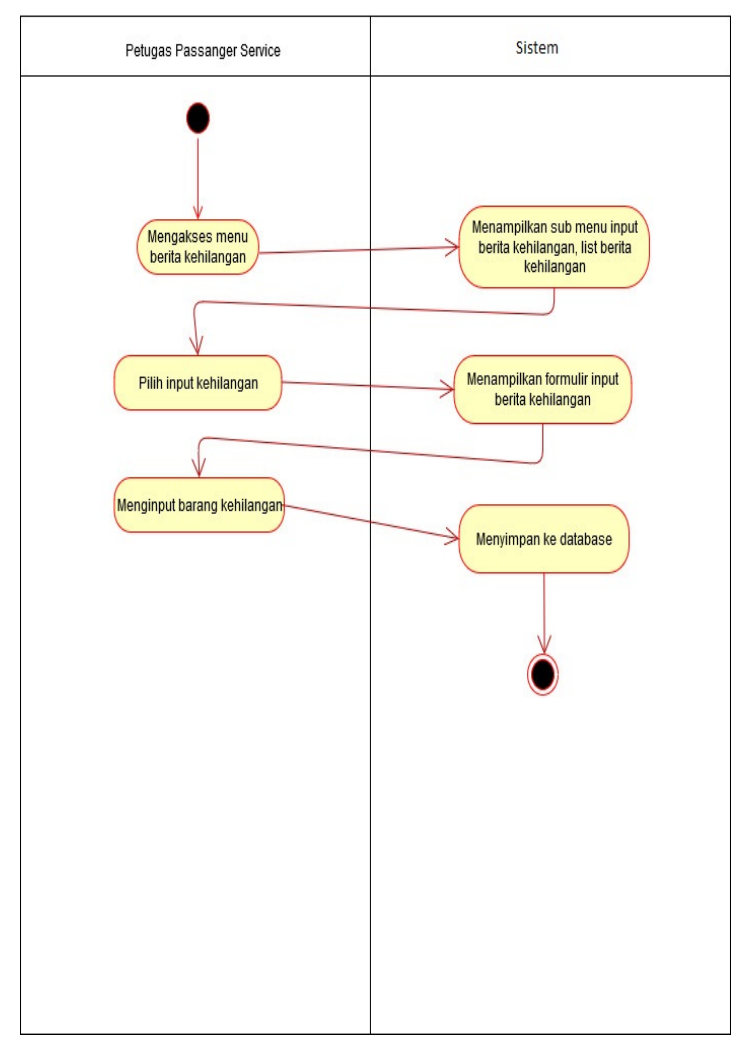

Gambar 6. Activity Diagram Input Berita Kehilangan

Berikut adalah penjelasan Activity Diagram Input Berita Kehilangan

1. Petugas mengakses menu berita kehilangan

2. System menampilkan submenu input berita kehilangan/list

3. Petugas pilih input kehilangan

4. System menampilkan formulir input berita kehilangan

5. Petugas menginput data berita kehilangan System menyimpan ke database
Activity Diagram Input Barang Temuan

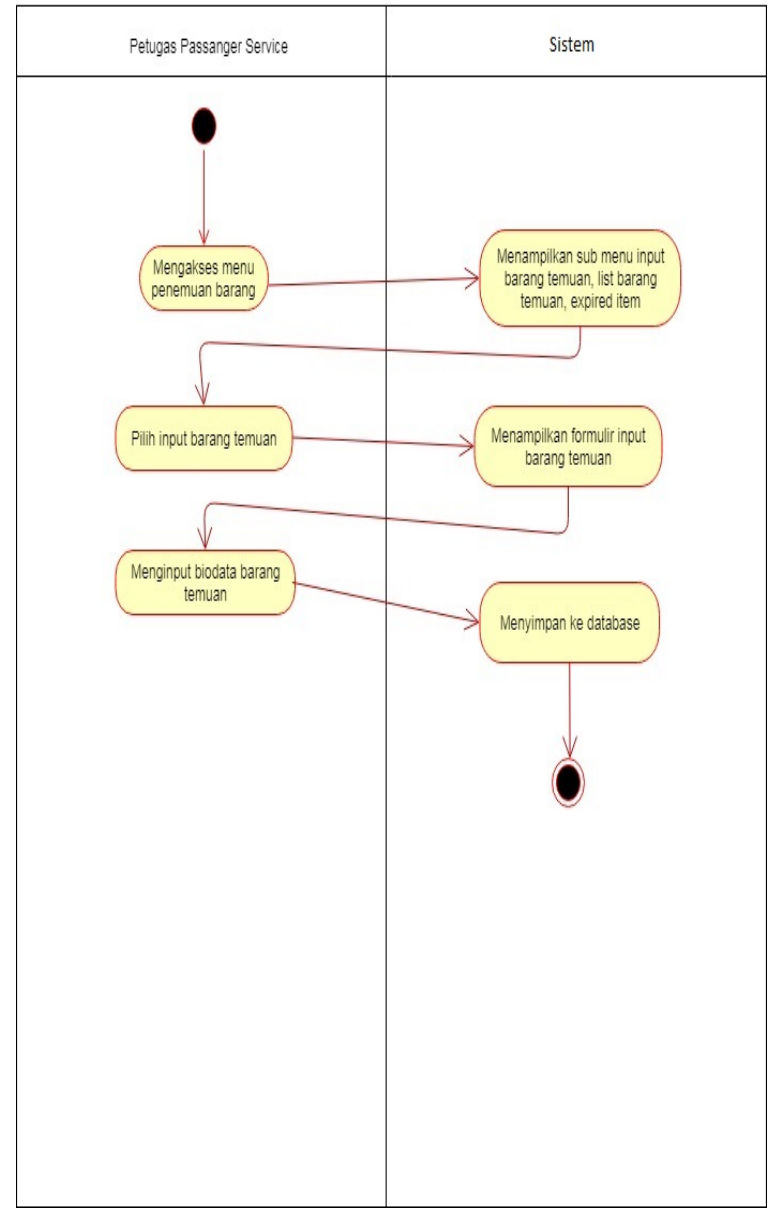

Gambar 7. Activity Diagram Input Barang Temuan

Berikut adalah penjelasan Activity Diagram Input Barang Temuan

1. Petugas mengakses menu penemuan barang

2. System menampilkan submenu input barang temuan/list

3. Petugas pilih input barang temuan

4. System menampilkan formulir input barang temuan

5. Petugas menginput biodata barang temuan

6. System menyimpan kedatabse 
Activity Diagram Diagram Activity

\section{Pengambilan Barang}

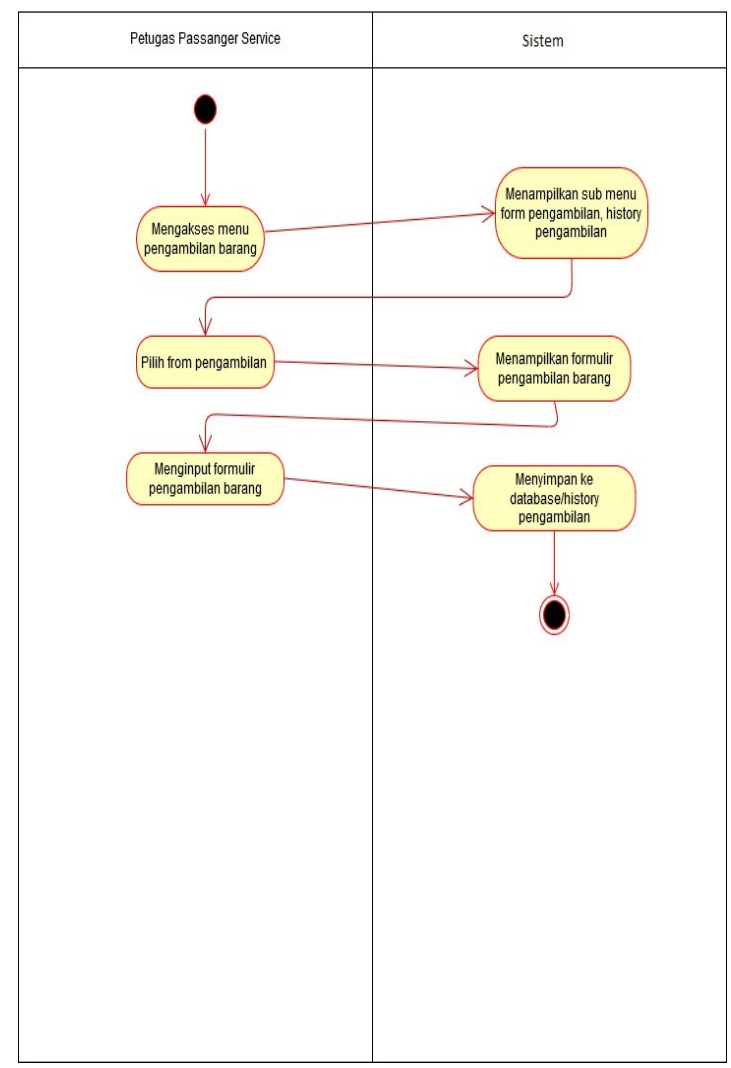

Gambar 8. Activity Diagram Pengambilan Barang

Berikut adalah penjelasan Activity Diagram Pengambilan Barang

1. Petugas menu pengambilan barang

2. System menampilkan submenu form pengambilan barang/history pengambilan

3. Petugas pilih form pengambilan

4. System menampilkan formulir pengambilan barang

5. Petugas menginput biodata pengambilan barang

6. System menyimpan kedatabase dan history pengambilan

\section{Diagram Class}

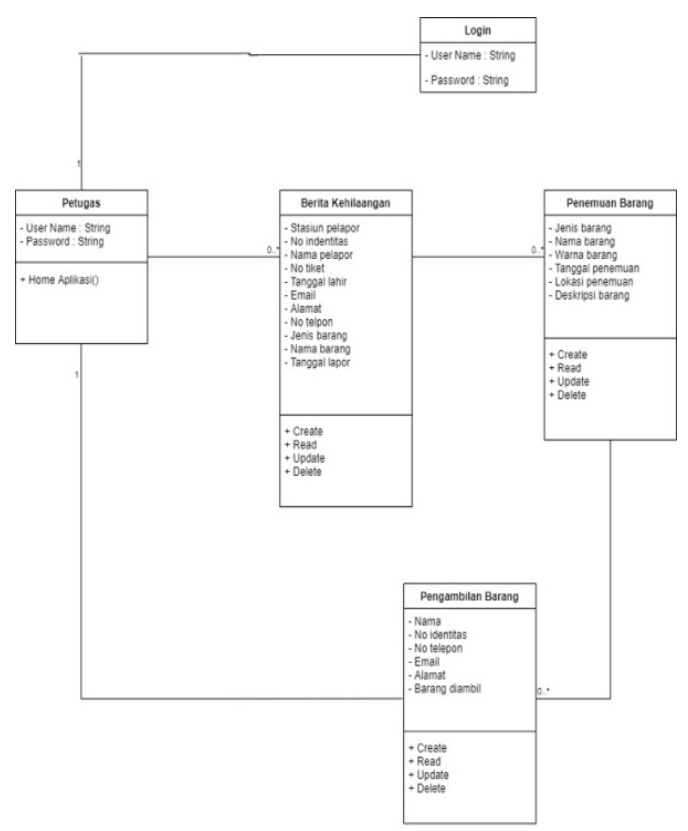

Gambar 9. Diagram Class

\section{Tampilan Aplikasi}

\section{Login}

Android Emulator - Android_APL_23:5554

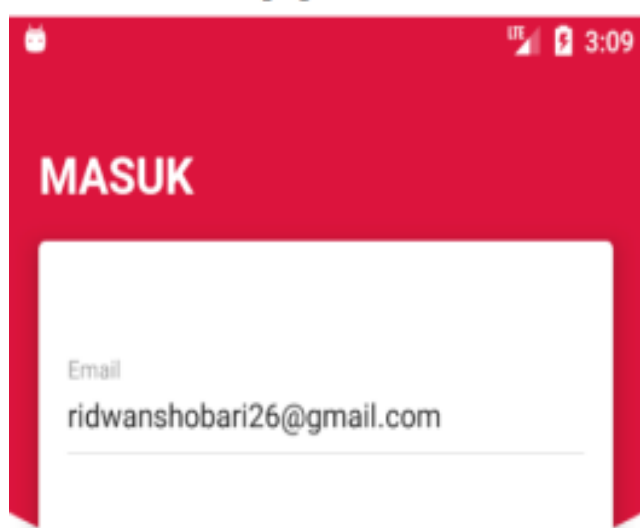

Kata Sandi

.........

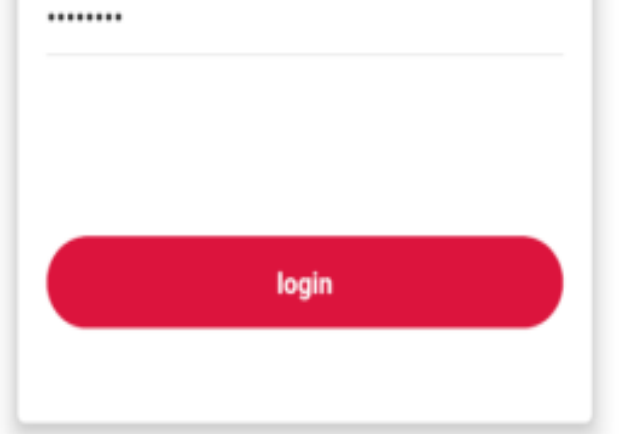

Gambar 10. Tampilan Login 


\section{DashboarPencarian Barang}

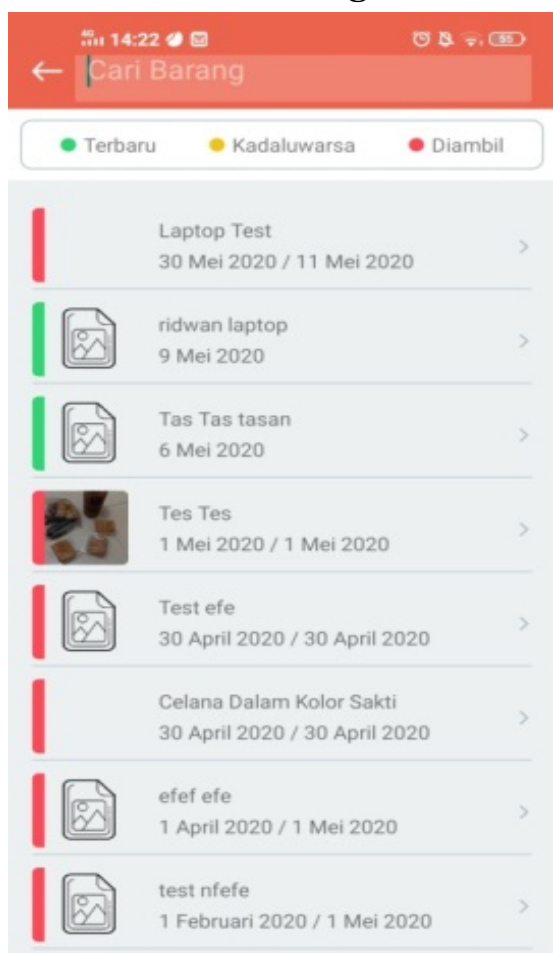

Gambar 11. Tampilan Pencarian Barang

\section{Input Berita Kehilangan}

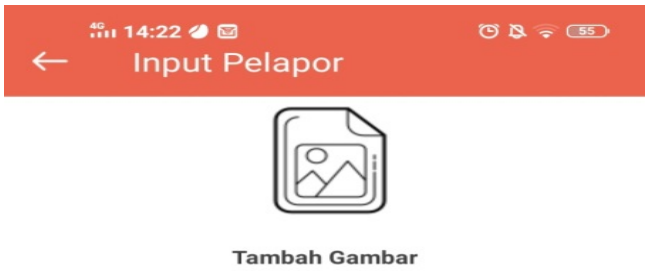

Stasiun Pelapor

\begin{tabular}{l} 
No Identitas \\
\hline Nama Pelapor \\
\hline No Tiket \\
\hline Tanggal Lahir \\
\hline Email \\
\hline Alamat
\end{tabular}

\section{Kirim}

Gambar 13. Tampilan Input Berita Kehilangan

\section{List Berita Kehilangan}

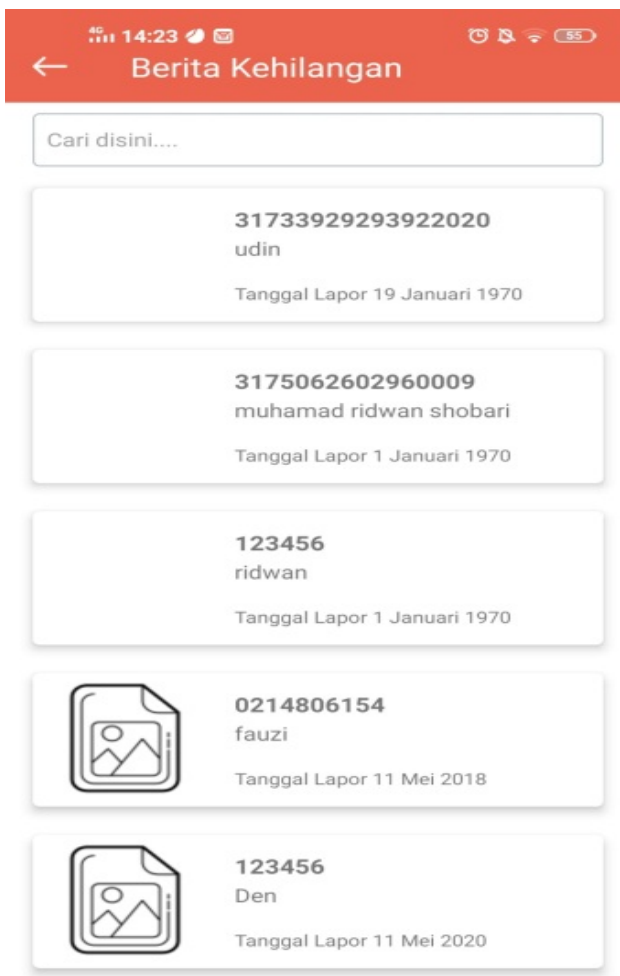

Gambar 12. Tampilan List Berita

Kehilangan

\section{Input Penemuan Barang}

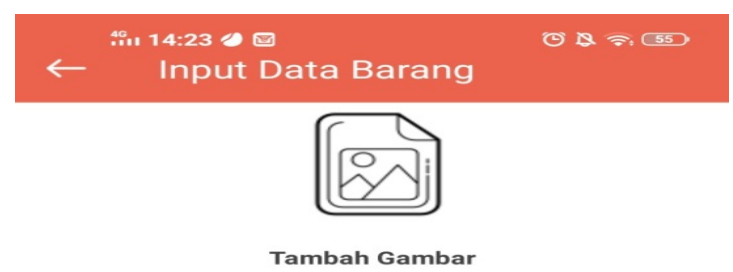

Jenis Barang

Nama Barang

Warna Barang

Tanggal Penemuan

Lokasi Penemuan

Deskpripsi Barang

Gunakan koma untuk pemisah (hp, warna kuning...)

\section{Kirim}

Gambar 14. Tampilan Input Penemuan Barang 


\section{List Penemuan Barang}

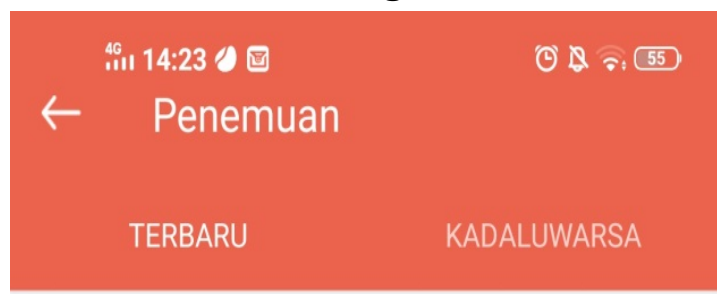

Cari disini...

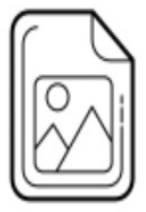

Tas Tas tasan

Warna kuning

Tanggal Kehilangan 6 Mei 2020

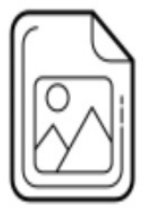

ridwan laptop

awjnawnda

Tanggal Kehilangan 9 Mei 2020

Gambar 15. Tampilan List Penemuan Barang

\section{Form Pengambilan Barang}

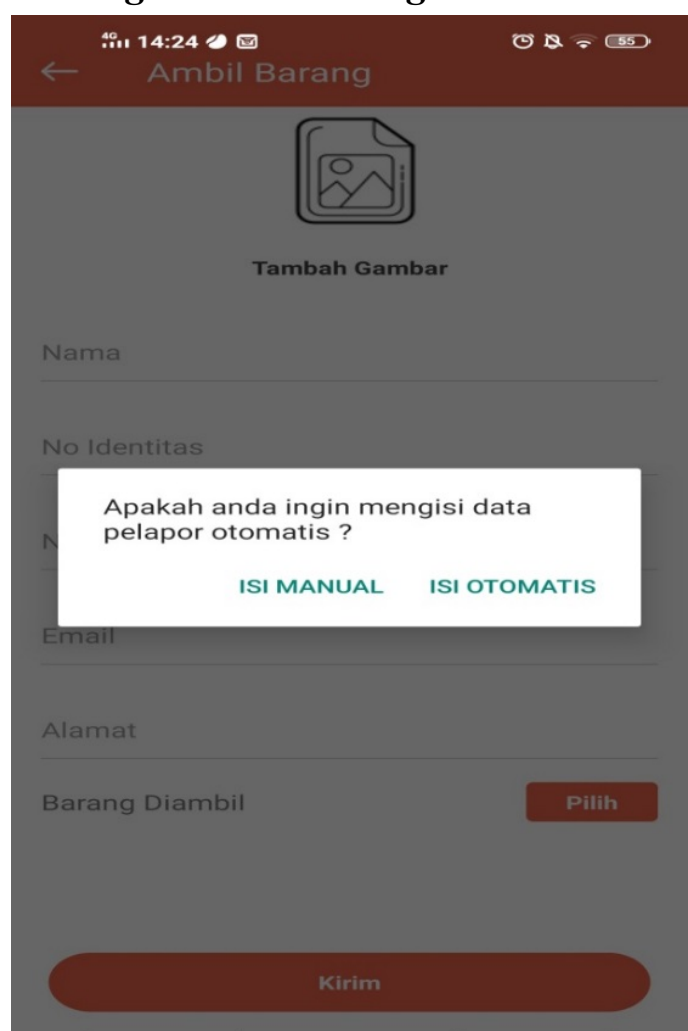

Gambar 16. Tampilan Form Pengambilan Barang

\section{Riwayat Pengambilan Barang}

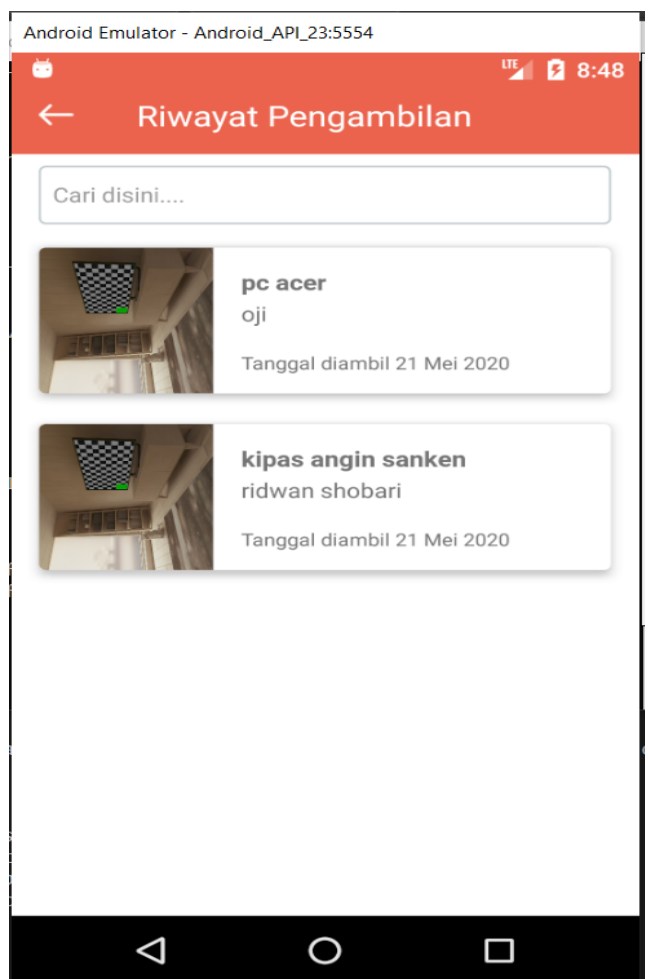

Gambar 17. Tampilan Pengambilan Barang

\section{Tentang Aplikasi}

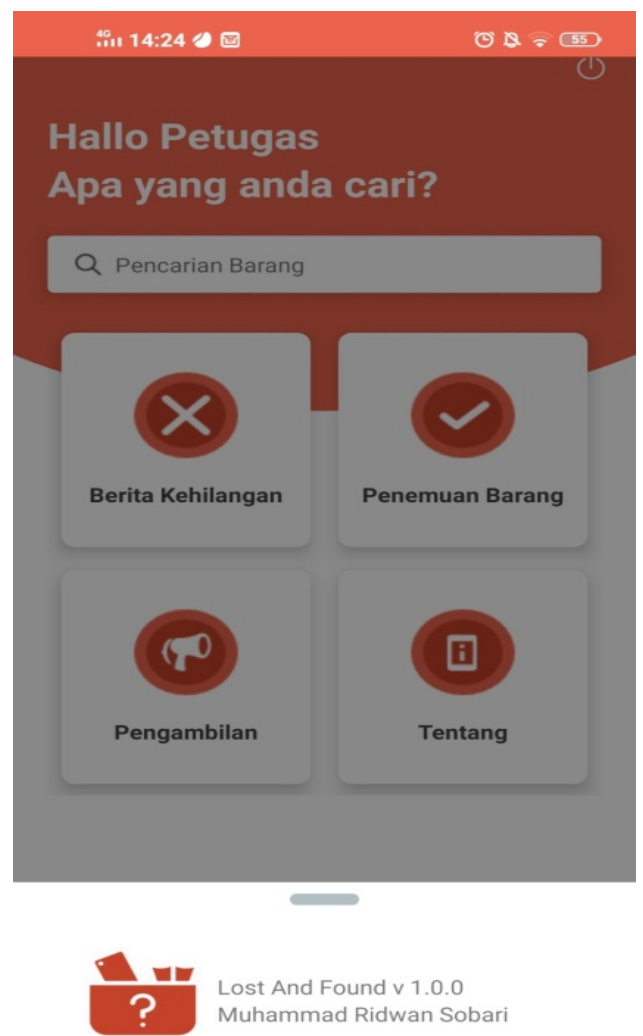

Gambar 18. Tampilan Tentang Aplikasi 


\section{KESIMPULAN}

1. Penelitian ini menghasilkan aplikasi yang dapat digunakan oleh PT. Kereta Commuter Indonesia untuk melakukan proses pelaporan barang kehilangan maupun barang temuan secara digital.

2. Aplikasi ini memberikan fitur yang dapat digunakan oleh petugas passanger service dalam melakukan pelaporan atau pencaarian barang kehilangan dan barang temuan.

3. Rancangan aplikasi yang dibuat dapat menggantikan penginformasian informasi melalui telfon menjadi digital mobile sesuai dengan kebutuhan petugas passanger service.

\section{DAFTAR PUSTAKA}

[1] Angela malau, “Arsitektur system informasi menggunakan togaf: strategi peningkatan keamanan pada perusahaan jasa pengiriman," E-journal sistem informasi., vol 11, no1, 2019.

[2] Handrie Noripson, Budiyarti, "Aplikasi manajemen pemeliharaan produk perangkat lunak," Journal scientific and applied informatics., vol 1, 2018.

[3] Arbi Juniar Setiawan, Ucuk Darusalam, dan Septi Andryana, "Rekayasa perangkat lunak aplikasi keputusan multi kriteria dengan algoritma Analytic Network Process berbasis android," JSI., vol 14, 2018.

[4] Denti Denita Putri, "Pengembangan learning management system menggunakan framework codeigniter dan angularjs di PT. XYZ," Jurnal Sistem Informasi (Journal of Information System)., vol 14, 2018.

[5] Harry Purnomo dan Nani K. Tachjar, "Aplikasi administrative surat menyurat menggunakan metodologi pemodelan berbasis objek," Jurnal Sistem Informasi (Journal of Information System)., vol 10, 2014.
[6] Mohamad Tri Wicaksono dan Benny Ranti, "Kajian profilsasi asset informasi menggunakan information asset profiling dan kuantifikasi nilai ekonomisnya berdasarkan analisis risiko pada industry rumah sakit," Jurnal Sistem Informasi (Journal of Information System)., vol 7, 2011.

[7] Miftahul Maulana dan Dana Indra, "Perancangan strategis system informasi: studi kasus direktorat jendral penyelenggaraan haji dan umroh departemen agama ri," Jurnal Sistem Informasi (Journal of Information System)., vol 7, 2011.

[8] Muh. Abdur Rohman, Beta Noranita, dan Andi Wibowo, "Pembangunan prototype system informasi administrasi kependudukan berbasis data terdistribusi," Jurnal Sistem Informasi (Journal of Information System)., vol 6, 2010.

[9] Fajar Masya, "Sistem pelayanan pengaduan masyarakat pada divisi humas polri berbasis web," International Journal of Computer Science and Mobile Computing,, vol 7, 2012.

[10] Fajar Masya, "Aplikasi system inspeksi bus berbasis web pada terminal bus pulogebang," Juss (Jurnal Sains Dan Sistem Informasi)., vol 1, 2018.

[11] A. Supriyatna dan V. Maria, "Analisis Tingkat Kepuasan Pengguna dan Tingkat Kepentingan Penerapan Sistem Informasi DJP Online dengan Kerangka Pieces," Khazanah Informatika, 211jurnal Teknologi \& Manajemen Informatika VOL.4 NO.2 2018 Jurnal Teknologi \& Manajemen Informatikavol., Volume 3, p. $1,2017$.

[12] Budi Prasetyo, "Perancangan dan Pembuatan Sistem Informasi Gudang (Studi Kasus : PT. PLN (Persero)," Ejournal.ikado., vol 4, 2015.

[13] Dadi Rosadi, Feby Oktarisa Andriawan, "Aplikasi Sistem Informasi Pencarian Tempat Kos Di Kota Bandung Berbasis Android," Jurnal computech \& bisnis., vol 10, 2016. 
[14] Bachti, "Seberapa besar pengaruh penggunaan tabloid Kontak terhadap pemenuhan kebutuhan infromasi karyawan di PT. Kereta Api Indonesia (persero) Daerah Operasi 1 Jakarta?", vol $5,2015$.

[15] http://www.krl.co.id.

[16] Ryan Muhamad, "Definisi, jenis-jenis, dan ciri-ciri laporan," 2013.

[17] Parta Setiawan, "Pengertian informasi," 2020. 